\title{
SHORT COMMUNICATION \\ INDUCTION OF FEMALE ORGANS IN STAMINATE GRAPE BY 6-SUBSTITUTED ADENINE DERIVATIVES
}

\author{
MUNEO IIZUKA AND TAKESHI HASHIZUME* \\ Horticultural Research Station, Ministry of Agriculture and Forestry, Hiratsuka, \\ Kanagawa-ken 254, and *Department of Food Science and Technology, \\ Kyoto University, Kyoto 606
}

Received September 14, 1968

The cytokinin, 6-benezylamino-9-(2-tetrahydropyranyl)-purine (BTP) can induce hermaphroditic flowers in staminate plants of Vitis vinifera (Negi and Olmo 1966) and $V$. thunbergii (Iizuka 1967) and makes possible the selfing of such plants. The present study was conducted to discover other chemicals which affect sex expression in Vitis spp. The cytokinins, 6-benzyladenine (BA) and 6-benzyladenosine (BAS), chosen from a group of 6 -substituted adenine derivatives synthesized by one of the authors (T. H.) were tested along with BTP, gibberellic acid (GA), 3-indoleacetic acid (IAA), and spermine tetrahydrochloride. BA, GA, and IAA were applied in a 2-percent alcohol solution at $1,000 \mathrm{ppm}$; BAS was applied in a 5-percent propylene glycol solution at $1,000 \mathrm{ppm} ; \mathrm{BTP}$ in a 5 -percent isopropanol solution at $1,000 \mathrm{ppm}$ and spermine in an aqueous solution at $1,000 \mathrm{ppm}$. Airol-OP at 0.1 percent was added to the solutions as a wetting agent. Blanks without the test chemicals were run in each assay with essentially no effect in respect to sex conversion.

Species tested included Vitis coignetiae Pulliat, V. thunbergii var. typica Makino, $V$. linsecomii Buckley, V. aestivalis Michaux, $V$. vulpina L. and $V$. labrusca $\mathrm{L}$. Each species shows segregation for "male" and "female" individuals under natural

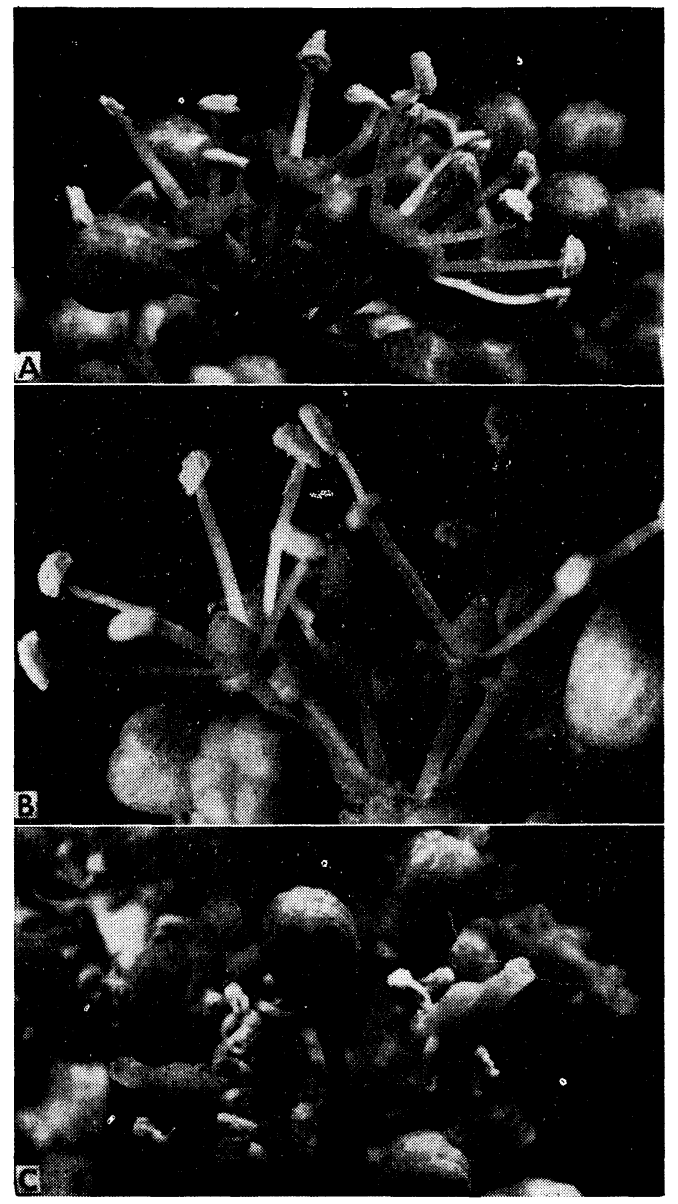

Fig. 1. Modification of flowers in $V$. thunbergii.

A: Untreated flowers in "male" vines. B : Hermaphroditic flowers induced with 6benzyladenine in "male" vines. C: Untreated flowers in "female" vines. 
Table 1. Effect of 6-benzyladenine on female organ induction of staminate $V$. thunbergii

\begin{tabular}{lcccc}
\hline $\begin{array}{l}\text { Sex of } \\
\text { vine }\end{array}$ & $\begin{array}{c}\text { Application date } \\
\text { in days before } \\
\text { anthesis }\end{array}$ & $\begin{array}{c}\% \text { Flowers with } \\
\text { female organs }\end{array}$ & $\begin{array}{c}\% \text { Pollen } \\
\text { stainability }\end{array}$ & Fruit set \% \\
\hline Male & 14 & 0 & 98 & - \\
& 19 & 100 & 97 & 20 \\
& 24 & 100 & 98 & 35 \\
Female & 10 & 100 & $97 *$ & 60 \\
\hline
\end{tabular}

* Stainable with acetocarmine, but non germinative.

populations. At intervals from 14 to 37 days before anthesis, flower clusters from "male" vines of each species and "female" vines from $V$. coignetiae and $V$. thunbergii were dipped in the above solutions. Two individuals of each species and three flower clusters, each on a different shoot, were treated with adjacent clusters on the same shoots as controls. Flower development was compared at anthesis, and fruit setting was observed 70 days after anthesis. Both BA and BAS as well as BTP promoted the formation of female organs in "male" plants. The clusters treated 18-35 days before anthesis produced typical hermaphroditic flowers showing pistils with mucus on stigmas, upright stamens with functional pollen grains, and normal fruit set (Fig. 1, Table 1). The clusters treated 14-17 days before anthesis were affected slightly having only a portion of the stigma or poorly developed pistils and no fruit development, or unaffected without any formation of pistils. Clusters from the "male" vine treated with GA, IAA and spermine showed no alteration of sex expression but GA elongated clusters, IAA and spermine reduced flower size. Cytokinin treatment of "female" vines failed to transform sex expression except for pistil enlargement and slight anther deformity.

One genetic explanation of sex determination in Vitis assumes that functional dioeciousness is controlled by two closely linked genes, So and $S p$. So is a dominant gene which suppresses ovule development and $S p$ is a dominant gene which promotes normal pollen development (Oberle 1938). According to this hypothesis, "female" individuals are of the genotypes so $s p / s o s p$, and "male" individuals so $s p / S o S p$. Each of the three cytokinins apparently bypasses the genetic regulatory mechanisms of $S o$ as a suppressor of ovule development. These results lead us to believe that the morphogenesis of female organs in Vitis is regulated by a key substance, such as endogenous cytokinin, possibly a 6 - or 1-substituted adenine derivative during a specific stage of flower development.

We thank Dr. Jules Janick, Purdue University, Lafayette, Indiana, U.S. A. for valuable suggestion.

\section{LITERATURE CITED}

Iizuka, M., 1967 Sex conversion in male Vitis, monoecious Castanea and Diospyros. Japan. J. Breed. 17, Suppl. 2: 117-118 (in Japanese).

Negi, S. S., and H. P. Olmo, 1966 Sex conversion in male Vitis vinifera L. by a kinin. Science 152: $1624-1625$.

Oberle, G. D., 1938 A genetic study of variations in floral morphology and function in cultivated forms of Vitis. N. Y. State Agri. Expt. Sta. Bulle. 250: 1-63. 